\title{
Ortaokul Öğrencilerinin Kesir Kavramına ilişkin Ürettikleri Metaforlar ${ }^{1}$
}

\author{
DOI: 10.26466/opus.639306 \\ * \\ Hakan Ergöl* - Dilek Sezgin Memnun** \\ * Milli EğitimBakanlığı, Sınıf Öğretmeni / İstanbul/ Türkiye \\ E-Posta: hakanergol@hotmail.com \\ ORCID: $\underline{0000-0001-6279-1301}$ \\ ** Doç. Dr, Bursa Uludağ Üniversitesi, Eğitim Fakültesi, Bursa / Türkiye \\ E-Posta: dilekmemnun@gmail.com \\ ORCID: $\underline{0000-0003-3254-8858}$
}

Öz

Gündelik yaşamımızda ve disiplinler arası çalışmalarda yer alan kesir kavramı, matematik öğretiminde öğrencilerin anlamada ve çözmede zorlandıkları kavramlardan biri olarak karşımıza çıkmaktadır. Son yapılan matematik programı değişimlerinin ardından da, bu kavramın somut materyaller ve günlük yaşamlarında tanıdıkları nesneler üzerinden kavratılması önem kazanmıştır. Çünkü bu program değişikliklerinde kesir kavramının öğretimine ilkokuldan itibaren yer verilmektedir. Bu değişimlerin ve yeniliklerin ardından, öğrencilerin kesir kavramını algılama biçimleri matematik öğretimi bağlamında incelenmelidir. Bu nedenle, bu çalışmada ortaokul öğrencilerinin kesir kavramına bakış açıları ile algılama biçimlerinin incelenmesi kararlaştırılmıştır. Bu kapsamda, araştırmaya katılan ortaokul öğrencilerinin kesir kavramına ilişkin metaforlarının ortaya koyulması amaçlanmıştır. Ayrıca, beşinci ve yedinci sinıf öğrencilerinin ürettikleri bu metaforlar arasındaki değişimlerin incelenmesine de yer verilmiştir. Çalışma sonucunda, öğrencilerin kesir kavramına ilişkin olarak toplam 115 farklı metafor ürettikleri açıklanmıştır. Bu kapsamda, araştırmaya katılan öğrencilerin en çok pasta/pizza, bıçak/makas, bütünü parçalama ve hayat metaforlarım oluşturduklarl görülmüştür. Bununla birlikte, yaş düzeyinin artması ile birlikte öğrencilerin kesri soyut metaforlarla açıklamaya başladıkları da anlaşılmıştır. Ayrıca; öğrencilerin bir bölümünün ürettikleri metaforlardan, bu öğrencilerin kesir kavramının anlamını ve kullanım amacını tam olarak kavrayamadıkları da anlaşılmıştır.

Anahtar Kelimeler: Kesir, Metafor, Ortaokul öğrencisi

\footnotetext{
1 9-11 Nisan 2018 tarihlerinde İstanbul'da yapılan "The 1st International Congress on New Horizons in Education and Social Sciences" isimli konferansta sunulmuş ve özet olarak yayınlanmış olan bildirinin genişletilmiş ve düzenlenmiş tam metnidir.
} 


\title{
Middle School Students' Metaphors about Fraction
}

\begin{abstract}
The concept of fraction which exists in our daily lives and interdisciplinary studies is one of the concepts that students have difficulty in understanding and solving in mathematics teaching. After the recent changes in the mathematics program, teaching this concept through concrete materials and familiar objects that they know in their lives has gain importance. Because, teaching of the concept of fraction is given from the first grade of primary school in these program changes. Following these changes and innovations, there is a need to re-examine the ways which students perceive the concept of fraction in the context of mathematics teaching. Therefore, it was examined the perspectives of the middle school students on the concept of fraction and the perception ways of the fraction concept of the middle school students; and in this context it is aimed to reveal the metaphors of the concept of fraction of the students who participated in the research. In addition, the analysis of the differences between the metaphors produced by the fifth and seventh grade students was also included. Through this study, it was observed that the students who participated in the research mostly consisted of "cake / pizza", "knife / scissors", "shredding whole" and "life" metaphors. Nevertheless, it was understood that using more abstract metaphors was increased with the age of the students. Also, when the metaphors produced by some of the students were examined, it was understood that these students could not fully understand the meaning and the purpose of the concept of fraction.
\end{abstract}

Keywords: Fraction, Metaphor, Middle school student 


\section{Giriş}

Sayıların insanların hayatına girmesi milattan önceki dönemlere dayanmaktadır. Öncelikle yerleşik yaşamla birlikte sayılara duyulan ihtiyaç ve ardından da merak dürtüsüyle ortaya çıkan matematiğin keşfi ve bu süreçler içerisinde rasyonel sayıların ortaya çıkışıyla sayılar matematik tarihi içerisinde yoğun biçimde yer almıştır. Tam sayıların insanların gündelik hayatta karşılaştıkları durumları çözmede yetersiz kalması rasyonel sayıların ortaya çıkışına neden olmuştur. Bu kapsamda, bu araştırmada ele alınacak olan ve farklı uzmanlık alanlarındaki hesaplamalarda kullanılan temel bir kavram olan kesir kavramı da giderek önem kazanmıştır (Walle, Karp ve Bay-Williams, 2013; Akt. Macit ve Nacar, 2019).

Ülkemizde 2005 yılı ve sonrasında gerçekleştirilen köklü program değişiklikleri öncesinde kesir kavramı, ilköğretim ilk kademelerinde "kesirler, bayağı kesirler, kesirli sayılar", ilerleyen kademelerinde ise "Rasyonel Sayılar" adıyla matematik derslerinde yer almakta idi (Şiap ve Duru, 2004: 89). Üstelik matematik derslerinde yer alan kesirler ve rasyonel sayılar konuları ilköğretim ve lise düzeyinde oran-orantı, ondalıklar, yüzdeler, olasılık, ölçme gibi matematiğin diğer konularının öğretimine de temel teşkil etmektedir. Ayn zamanda, meslek yaşamında ve günlük hayatta ölçme ve hesaplamalarda oldukça sık başvurulan konulardır (Macit ve Nacar, 2019). Kesirler ve kesirlerle işlemlere yönelik kavramsal anlamların oluşturulması da, özellikle cebir gibi ileri düzeydeki konuların öğreniminin yanında problem çözme becerilerin gelişimi için de önemlidir. Bu nedenle, geçmiş dönemlerdeki bu matematik öğretim programlarında kesir kavramının öğretimine üçüncü sınıftan itibaren başlanırken, 2018 yılı Matematik Ders Programi'nda kesirler konusunun öğretimine ilkokul birinci sınıftan başlayarak yer verilmektedir. Bu kapsamda, ilk yıllarda bütün ve yarım kesirler ile ilgili farkındalık oluşturulmakta, bütün ve yarımın çeyrek ile ilişkisi verilmekte, parça-bütün ilişkisi vurgulanarak kesire ait terimler tanitılmakta ve birim kesir kavramı ele alınarak pay ve payda arasındaki ilişki pekiştirilmektedir. İlerleyen yıllarda ise basit, bileşik ve tam sayılı kesri tanıma ve kullanma, kesirlerde toplama ve çıkarma işlemleri, tam sayılı ve bileşik kesirler arasında dönüşüm ve sıralama önem kazanmaktadır. Ortaokul yıllarında, ondalık gösterim konusu ele alınmaya başlanmakta, ondalık gösterimin kesirlerle ilişkilendirilmesi, ondalık kesirler- 
le toplama ve çıkarma işlemleri yapılması, yüzde kavramının kesir ve ondalık gösterimlerle ilişkilendirilmesi yapılmaktadır. Ayrıca, kesirleri sıralama, karşılaştırma ve kesirlerle dört işlem yapma, ondalık gösterimleri verilen sayıları çözümleme, bu sayılara ilişkin çarpma ve bölme işlemleri yapma konuları işlenmektedir. Bununla birlikte, ortaokul yıllarında rasyonel sayılar tanıtılarak karşılaştırılmakta ve rasyonel sayılarla dört işlem yapma ve rasyonel sayılarla problem çözme çalışmaları da yapılmaktadır. Bir kesir veya bir tam sayının bir tam sayıya oranı olarak temsil edilebilen tümsayıların kümesine Rasyonel Sayılar Kümesi denilmektedir (Walle, Karp ve Bay-Williams, 2013; Akt. Macit ve Nacar, 2019). Bununla birlikte, her kesir bir rasyonel sayı iken her rasyonel sayı bir kesir olmayabilir çünkü rasyonel sayılar kesirlerden farklı olarak ondalık sayı ya da yüzde şeklinde gösterilebilir (Lamon, 2007). Bu kapsamda, özellikle de ilkokulun ilk yıllarında kesir kavramının öğretiminde gerçek yaşam durumlarıyla ilişkilendirilip anlamlandırma önem taşımaktadır. Bununla birlikte, kesirler ve kesirlerle işlemler konusu öğrenciler için anlaşılması zor konuların başında gelmektedir (Charalambous ve Pantazi, 2005; Doğan ve Yeniterzi, 2011; Orhun, 2007; Önal ve Yorulmaz, 2017). Bu alanda yapılan bazı çalışmalarda (Birgin ve Gürbüz, 2009; Soylu ve Soylu, 2005; Yazgan, 2007; Yllmaz ve Yenilmez, 2008) da, farklı düzeylerden araştırmaya katılan bireylerin kesir kavramını anlama ve öğrenmede zorluk yaşadıklarını açıklanmıştır.

$\mathrm{Bu}$ araştırmalardan Haser ve Ubuz (2002) tarafından beşinci sınıf öğrencilerinin kesirler konusunda sahip oldukları bilgi ve becerilerin kavramsal ve işlemsel durumlarda kullanma performanslarının incelenmesi amacıyla gerçekleştirilen çalışmanın sonucunda, öğrencilerin aynı hedefi farklı durumlarda ölçen kavramsal performansa yönelik sorularda sorunun içerdiği kesir çeşitlerine göre performans gösterdikleri anlaşılmıştır. Ayrıca, işlemsel performansa yönelik sorularda ise farklı tipte kesirler arasındaki çıarma ve çarpma işlemlerinde toplama işlemine kıyasla daha düşük performans gösterdikleri de açıklanmıştır. Pesen (2007) tarafından üçüncü sınıf öğrencilerinin kesirlerle ilgili ortak hatalarının arkasında yatan kavram yanılgılarının belirlenmesi amacıyla gerçekleştirilen çalışmanın sonucunda, kesirlere uygun model çizmede öğrencilerin önemli bir bölümünün bütünü eş parçalara ayırmada başarılı olamadıkları, öğrencilerin dairesel şekilleri eş parçalara ayırmada dikdörtgensel şekillerden daha fazla zorlandıkları anlaşılmıştır. Bazılarının kesrin sembolik gösteri- 
mini tek bir sayı olarak algılamada zorluk çektikleri ve modellere ait kesir sayılarını ifade etmede güçlük yaşadıkları da çalışmanın sonucunda açılanmıştır. Ayrıca, öğrencilerin önemli bir bölümü kesir sayılarının okunuşlarına ait kesir sayılarını yazamadıkları da görülmüş ve bu öğrencilerin çoğunun pay yerine paydayı ve payda yerine de payı yazdıkları da anlaşılmıştır. Önal ve Yorulmaz (2017) tarafından yapılan çalışmada ilkokul dördüncü sınıf öğrencilerinin kesirler konusunda yaptıkları hataların belirlenmesi amaçlanmış ve çalışmanın sonucunda öğrencilerin kesirlerde en fazla yaptıkları hatalar kesirlerde sıralama yaparken doğal sayı gibi işlem yapma, toplama işleminde aynı kesir içerisinde pay ve paydayı toplayıp sonucu doğal sayı olarak yazma, çıarmada pay ve paydaları ayrı düşünüp büyük sayıdan küçük sayıyı çıkarma ve sayı doğrusunda bütünü parçalara eş olarak ayırmama olarak açıklanmıştır. Bu çalışmalarda, öğrencilerin bu zorluklarının da kavramın yapısı ve öğreniminden, kavramın ilkokul ve ortaokul seviyesindeki bireyler için soyut olmasından kaynaklandığı ifade edilmektedir.

Bilişsel öğrenme kuramı bireylerin yaklaşık onbir yaştan itibaren soyut işlemler dönemine geçmekte ve bu şekilde düşünebilmektedirler (Baykul, 2009; Senemoğlu, 2009). Bundan dolayı, ilkokul dönemindeki öğrenciler somut işlemler düzeyinde olduğu için kesir kavramının anlaşılması ve öğrenilmesi zorlaşmaktadır. Bu nedenle, kesir kavramının daha iyi anlaşılması açısından öğrencinin kesir kavramını zihninde hangi kavramlarla ilişkilendirdiğinin, hangi anlamlar yüklediğinin açıklanması gerekmektedir ve bunun için de metaforlardan yararlanılabilir. Metafor kelimesinin kökeni Fransızca "metaphore" kelimesinden gelmektedir. Metaforlar somut kavramlar içerdiği için ilgili kavramın tanımlanmasını güçlendirmektedir. Kesir kavramının öğretiminde karşılaşılan zorlukların kesirlerin günlük yaşamdan örneklerle ilişkilendirilerek aşılmaya çalışılması için ögrencilerin kesirlerle ilgili sahip oldukları metaforların ortaya koyulması önem taşımaktadır. Metaforlar aracılığı ile öğrencilerin kesirler konusunu öğrenirken zorlandıkları kavramlar, işlemler vb. tespit edilebilir ve kesir kavramının etkili öğretiminde izlenecek yöntemler açısından fikirler oluşturulabilir. Bu nedenle, bu çalışmada ortaokul beşinci ve yedinci sınıf öğrencilerinin kesir kavramına bakış açıları ile algılama biçimlerinin incelenmesi kararlaştırılmıştır. Bu kapsamda, araştırmaya katılan ortaokul öğrencilerinin kesir kavramına ilişkin metaforlarının ortaya koyulması 
amaçlanmıştır. Ayrıca, beşinci ve yedinci sınıf öğrencilerinin ürettikleri bu metaforlar arasındaki değişimleri de incelenmiştir. Bu kapsamda, aşağıda yer verilen araştırma problemlerine çözüm aranmaktadır:

1. Ortaokul öğrencilerinin kesirlerle ilgili sahip oldukları metaforlar nelerdir?

2. Ortaokul öğrencilerinin kesirlerle ilgili sahip oldukları metaforlar hangi temalar altında toplanabilir?

3. Ortaokul beşinci ve yedinci sınıf öğrencilerinin metaforlarının birbirinden ayrıldığı/farklılaştığı temalar var mıdır?

\section{Yöntem}

$\mathrm{Bu}$ kısımda, araştırmaya katılan ortaokul öğrencilerinin kesir kavramına ilişkin sahip oldukları metaforlarının ortaya koyulması amaciyla yapılan veri toplama ve analizine, araştırmaya katılan öğrencilere ilişkin detaylı bilgilere yer verilmiştir.

\section{Araştırma Modeli}

Bu çalışmada, ortaokul öğrencilerinin kesirlerle ilgili sahip oldukları metaforların ortaya koyulması amaçlandığı için olgubilim araştırması yapılmıştır. Olgu, "birtakım olayların dayandığı neden veya bu nedenlerin yol açtığı sonuç" olarak ifade edilebilir (Türk Dil Kurumu, 2019). Olgubilim (fenomenoloji) ise, bireyler tarafindan fark edilmekle birlikte hakkında net ve detaylı bilgiye sahip olunamayan olguları inceleyen bir araştırma türüdür (Cropley, 2002). Olgubilim araştırmalarında "veri kaynakları, araştırmanın odakland1ğ1 olguyu yaşayan ve bu olguyu dışa vurabilecek bireyler ya da gruplar"dır (Büyüköztürk, Kılıç-Çakmak, Akgün, Karadeniz ve Demirel, 2018).

\section{Çalışma Grubu}

Bu araştırmaya, 2017-2018 eğitim-öğretim yılı ikinci döneminde İstanbul ili Kağıthane ilçesinde bulunan Hamidiye İmam Hatip Ortaokulu'nda öğrenim görmekte olan ve araştırmacılardan birinin öğretmenleri olduğu 152 (\%51)'si beşinci sinıf ve 146 (\%49)'sı ise yedinci sınıf öğrencisi olmak üzere toplam 298 öğrenci katılmıştır. Araştırma kapsamına alınan okul İstanbul ili 
Kağıthane ilçesinde bulunan ortaokullar arasından olasilık temelli örnekleme yöntemlerinden biri olan seçkisiz örnekleme yöntemi ile belirlenmiştir. Seçkisiz örnekleme yönteminde, tamamen rastgele yöntemle örneklem seçilmektedir (Yıldırım ve Şimşek, 2005: 104). Araştırmaya katılan beşinci sınıf öğrencilerinin 73 (\%48)'ü ve yedinci sınıf öğrencilerinin 68 (\%46)'i kız öğrencidir.

\section{Verilerin Toplanması}

Araştırmaya katılan ortaokul öğrencilerine "Kesir .......gibidir. Çünkü ........." şeklindeki cümle yazılı olarak yöneltilmiştir. Çalışmaya katılma konusunda istekli olan öğrencilere anket kağıdındaki ilgili bölümlere kendilerinin ve sınıflarının isimlerini yazmaları istenmiş, öğrencilerin anket sorularını cevaplamaları 15 dakika civarında tamamlanmıştır.

\section{Verilerin Analizi}

Ortaokul öğrencilerinin kesir kavramına bakış açları ile algılama biçimlerinin incelenmesi ve kesir kavramına ilişkin metaforlarının ortaya koyulması amaçlarıyla gerçekleştirilen bu çalışmada elde edilen verilerin analizi betimsel analizi aracılığı ile gerçekleştirilmiştir.

Betimsel analizde, çeşitli veri toplama teknikleri ile elde edilmiş verilerin daha önceden belirlenmiş temalara göre özetlenmesi ve yorumlanmasını içeren bir nitel veri analizi türüdür. $\mathrm{Bu}$ analiz türünde temel amaç, elde edilmiş olan bulguların okuyucuya özetlenmiş ve yorumlanmış bir biçimde sunulmasıdır (Yıldırım ve Şimşek, 2005). Betimsel analiz dört aşamadan oluşur. Bunlar; betimsel analiz için bir çerçeve oluşturma, tematik çerçeveye göre verilerin işlenmesi, bulguların tanımlanması ve bulguların yorumlanması aşamalarıdır (Altunışık, Coşkun, Yıldırım ve Bayraktaroğlu, 2010). Bu araştırma kapsamında ilk aşama olan betimsel analiz için bir çerçeve oluşturma aşamasında, birinci araştırma problemi veri analizi için en genel düzeydeki çerçeveyi oluşturmuştur. Tematik çerçeveye göre verilerin işlenmesi aşamasında, belirlenen çerçeveye göre birinci araştırma problemi için veriler somut bir nesnelfiziksel olarak yapılan iş, soyut bir kavram, benzetim, olumsuz algl, olumlu algı ve kesir gösterimi ile ilişkili olmak üzere 6 farklı tema altında düzenlenmiş ve sunulmuştur. Bulgularm tanmmlanması ve yorumlanması aşamasında ise, belirlenen temalara göre elde edilen veriler okunmuş 
ve düzenlenmiştir. Ardından, düzenlenen veriler tablo ve şekillerde sunulmuş ve ulaşılan bulgular bu temalar üzerinden yorumlanmıştır. Son olarak da, araştırma bulguları gerekli yerlerde doğrudan alıntılarla desteklenmiştir.

\section{Bulgular ve Yorum}

Bu çalışmada, ortaokul öğrencilerinin kesirlerle ilgili sahip oldukları metaforlar araştırılmış ve elde edilen bulgular bu kısımda sunulmuştur. Buna göre, ilk olarak "Ortaokul öğrencilerinin kesirlerle ilgili sahip oldukları metaforlar nelerdir?" biçimindeki araştırma problemine cevap aranmıştır. Bu kapsamda, araştırmaya katılan öğrencilerin geçerli 115 çeşit metafor ürettiği ve bu metaforların sayısının 298 olduğu aşağıda yer alan tablodan anlaşılmaktadır.

Tablo 1. "Kesir" Kavramı ile ilgili Üretilen Metaforlar

\begin{tabular}{|c|c|c|c|c|c|}
\hline Metafor & $\mathrm{f}$ & $\%$ & Metafor & $\mathrm{f}$ & $\%$ \\
\hline Pasta/Pizza & 88 & 29.54 & Her şey & 1 & 0.34 \\
\hline Bıçak/Makas & 19 & 6.38 & İnsan & 1 & 0.34 \\
\hline Bütünü Parçalama & 10 & 3.36 & İnsan Karakteri & 1 & 0.34 \\
\hline Hayat & 10 & 3.36 & İnsanların Siraya Girmesi & 1 & 0.34 \\
\hline Tren & 9 & 3.02 & Kâğıdın Parçasııı Boyama & 1 & 0.34 \\
\hline Kitap & 8 & 2.69 & Kâğıt & 1 & 0.34 \\
\hline Matematik & 7 & 2.34 & Kalem & 1 & 0.34 \\
\hline Geometrik Şekiller & 6 & 2.01 & Fetih & 1 & 0.34 \\
\hline Kek & 5 & 1.67 & Futbol & 1 & 0.34 \\
\hline Para & 5 & 1.67 & Gözlük Çerçevesi & 1 & 0.34 \\
\hline Bölünme & 3 & 0.97 & Güneş & 1 & 0.34 \\
\hline Çikolata & 3 & 0.97 & Evren & 1 & 0.34 \\
\hline Ev & 3 & 0.97 & Karenin Parçaları & 1 & 0.34 \\
\hline Meyve & 3 & 0.97 & Kesici Alet & 1 & 0.34 \\
\hline Araba & 3 & 0.97 & Kesilmiş İrmik (heceleri) & 1 & 0.34 \\
\hline Atom & 3 & 0.97 & Kesme İşareti & 1 & 0.34 \\
\hline Bölme & 2 & 0.66 & Kilo Alma-Verme & 1 & 0.34 \\
\hline Bütün & 2 & 0.66 & Kitap Ayracı & 1 & 0.34 \\
\hline Ekmeği Bölmek & 2 & 0.66 & Kuş & 1 & 0.34 \\
\hline İğne & 2 & 0.66 & Labirent & 1 & 0.34 \\
\hline İki Odayı Ayıran Duvar & 2 & 0.66 & Lego Parçaları & 1 & 0.34 \\
\hline Işın & 2 & 0.66 & Makas Kelime Çağrışımı & 1 & 0.34 \\
\hline Karadelik & 2 & 0.66 & Masa & 1 & 0.34 \\
\hline Kesen Çizgi & 2 & 0.66 & Matematik dersi & 1 & 0.34 \\
\hline Korku-Dehşet-Karanlık & 2 & 0.66 & Matematik programı & 1 & 0.34 \\
\hline Paralel & 2 & 0.66 & Menekşe & 1 & 0.34 \\
\hline Pay-Payda-Bütün & 2 & 0.66 & Müebbet Hapis Cezası & 1 & 0.34 \\
\hline
\end{tabular}




\begin{tabular}{llllll}
\hline Saat & 2 & 0.66 & Nesrin (Özel İsim) & 1 & 0.34 \\
Yatay Çizgi & 2 & 0.66 & Not & 1 & 0.34 \\
Arkadaşlık & 2 & 0.66 & Okul & 1 & 0.34 \\
Fen Dersi & 2 & 0.66 & Oran & 1 & 0.34 \\
Ayrı Bölmeli Eşyalar & 1 & 0.34 & Orman & 1 & 0.34 \\
Bilgisayar Masaüstü E. & 1 & 0.34 & Otel & 1 & 0.34 \\
Bıçak & 1 & 0.34 & Oyun & 1 & 0.34 \\
Bölen & 1 & 0.34 & Papatya & 1 & 0.34 \\
Bölünen Her Şey & 1 & 0.34 & Parçanın Bölümleri & 1 & 0.34 \\
Brokoli & 1 & 0.34 & Paylaştırma Birimi & 1 & 0.34 \\
Bulmaca & 1 & 0.34 & Rasyonel Sayılar & 1 & 0.34 \\
Buzdolabı & 1 & 0.34 & Sayı Çubuğu & 1 & 0.34 \\
Bütün Oluşturma & 1 & 0.34 & Sayılardan Oluşan Şey & 1 & 0.34 \\
Bütünün Yarısı & 1 & 0.34 & Sayıları İfade Etme & 1 & 0.34 \\
Cam & 1 & 0.34 & Sonsuzluk Sembolü & 1 & 0.34 \\
Cetvel & 1 & 0.34 & Tahta & 1 & 0.34 \\
Çanta & 1 & 0.34 & Tam İnsan & 1 & 0.34 \\
Çapa & 1 & 0.34 & Terazi & 1 & 0.34 \\
Çaresi Olmayan Zehir & 1 & 0.34 & Testere & 1 & 0.34 \\
Çarpma İslemi Sembolü & 1 & 0.34 & Toplama İslemi & 1 & 0.34 \\
Defter & 1 & 0.34 & Uçak & 1 & 0.34 \\
Deniz & 1 & 0.34 & Uğur Böceği & 1 & 0.34 \\
Dilim & 1 & 0.34 & Uzay & 1 & 0.34 \\
Dipsiz Çukur & 1 & 0.34 & Uzun Yol & 1 & 0.34 \\
Dört İşlem & 1 & 0.34 & Yemek & 1 & 0.34 \\
Dünya & 1 & 0.34 & Yemek Dilimleri & 1 & 0.34 \\
Dünyada en temel konu & 1 & 0.34 & Yıldılar & 1 & 0.34 \\
Elma Dilimleri & 1 & 0.34 & Yuvarlak & 1 & 0.34 \\
Elmanın iki yarısı & 1 & 0.34 & Zürafa & 1 & 0.34 \\
Ev & 1 & 0.34 & Kırı & 1 & 0.34 \\
& & & (Arapça Kesir'in Karşllı̆ı) & & \\
\hline
\end{tabular}

Yukarıdaki tablodan anlaşılacağı üzere, araştırmaya katılan ortaokul öğrencileri tarafından en çok üretilen metaforların "Pasta/Pizza" (88\%24.54) ve "Bıçak-Makas" (19-\%6.37) olmuştur. Katılımcıların bir bütünü eş parçalara ayırmak için pastayı ya da pizzayı, bir kâğıdı kesme mantı̆̆1 ile katılımcıların "pasta/pizza" metaforuyla bağlantılı olarak "b1çak/makas" metaforunu ürettikleri görülmüştür. Parçalara ayırma işini metafor olarak gören katılımcılar ise "Bütünü parçalama" 10 metafor\%3.36) metaforu üretmiştir. Ayrica, "Hayat" (10 metafor-\%3.36) ve "Tren" (9 metafor-\%3.02) metaforları da öğrenciler tarafından en çok üretilen metaforlar olarak açiklanmıştır.

İkinci olarak "Ortaokul öğrencilerinin kesirlerle ilgili sahip oldukları metaforlar hangi temalar altında toplanabilir?" biçimindeki araştırma 
problemine cevap aranmıştır. Bu araştırma problemine cevap aranırken, araştırmaya katılan ortaokul öğrencileri tarafından üretilen metaforlar ve bu metaforları belirleme nedenleri olarak yaptıkları açıklamalar incelenmiştir.

Kesir kavramına ilişkin olarak ortaokul öğrencilerinin ürettikleri metaforlar "Somut bir nesne/Fiziksel olarak yapılan bir iş", "Soyut bir kavram", "Benzetim", “Olumlu alg1", “Olumsuz algı" ve "Kesir gösterimi ile ilişkili” şeklinde altı farklı grupta toplanmış ve bu gruplarda yer alan metaforlara ilişkin betimsel analiz sonuçları da aşağıdaki tabloda sunulmuştur. $\mathrm{Bu}$ kapsamda, farklı temalarda yer alan metaforların sayısı ile yüzde ve frekans değerlerine Tablo 2' de yer verilmiştir.

Tablo 2. "Kesir" Kavramına ilişkin Temalar

\begin{tabular}{llr}
\hline Temalar & f & \% \\
\hline Somut bir nesne/Fiziksel olarak yapılan bir iş & 158 & 53.02 \\
Soyut bir kavram & 80 & 26.85 \\
Kesir gösterimi ile ilişkili & 25 & 8.39 \\
Olumsuz alg1 & 13 & 4.36 \\
Benzetim & 12 & 4.03 \\
Olumlu alg1 & 10 & 3.35 \\
\hline
\end{tabular}

Yapılan incelemeler, araştırmaya katılan ortaokul öğrencilerinin "Kesir" kavramına ilişkin olarak ürettikleri metaforların yarısından fazlasının (158 metafor-\%53.02) "Kesir" kavramın "Somut bir nesne/Fiziksel olarak yapılan bir iş" olarak açıklamıştır. Bu durum, araştırmaya katılan öğrencilerin bu kavramı somut durumlarla düşünüp açıkladıklarını gösterir niteliktedir. Öğrencilerin önemli bir kısmı (80 metafor-\%26.85) bu kavramı "Soyut bir kavram" olarak açılarken, az bir kısmı (12 metafor-\%4.03) ise benzetmelerden yararlanmıştır. Tabloda yer alan bilgilerden, ortaokul beşinci ve altıncı sınıf öğrencilerinin bir kısmının (25 metafor-\%8.39) ise oluşturdukları metaforlarda kesrin gösterimi ile ilgili ilişkilendirmeler kurdukları görülmüştür. Aynı zamanda, yukarıdaki tablodan olumlu öğrenci metaforlarınin (10 metafor-\%3.35) olumsuz metaforlara (13 metafor-\%4.36) kıyasla az sayıda olduğu da anlaşılmaktadır.

$\mathrm{Bu}$ araştırma kapsamında son olarak da, "Ortaokul beşinci ve yedinci sınıf öğrencilerinin metaforlarının birbirinden ayrıldığı/farklılaştığ1 temalar var mıdır?" biçimindeki araştırma problemine cevap aranmıştır. Bu 
aşamada, ilk olarak "Somut bir nesne/Fiziksel olarak yapılan bir iş" teması için inceleme yapılmış ve öğrencilerin ürettiği metaforların 158 (\%53.02)'inin günlük yaşamdan somut örneklerden oluştuğu anlaşılmıştır. Bu metaforların arasında en sik kullanılan metaforlar; "Pasta/Pizza", "B1çak/Makas", "Bütünü parçalama" ve "tren" metaforlarıdır. Bu kategori altında, beşinci sınıf öğrencileri (102 metafor-\%34.23) yedinci sınıf öğrencilerine (56 metafor-\%18.79) kıyasla daha çok sayıda metafor üretmiştir. Bu oranın yüksek olmasının, beşinci sınıf öğrencilerinin somut işlemler döneminde olmasından kaynaklandığı düşünülmektedir. Ayrıca, bu sınıf düzeyinde Matematik dersinde kesir konusu işlenirken daha çok somut örnekler üzerinden gidilmesinin etkili olduğu da söylenebilir. Aşağıda yer alan şekilde bu tema altında yer alan metaforlardan örneklere yer verilmiştir.

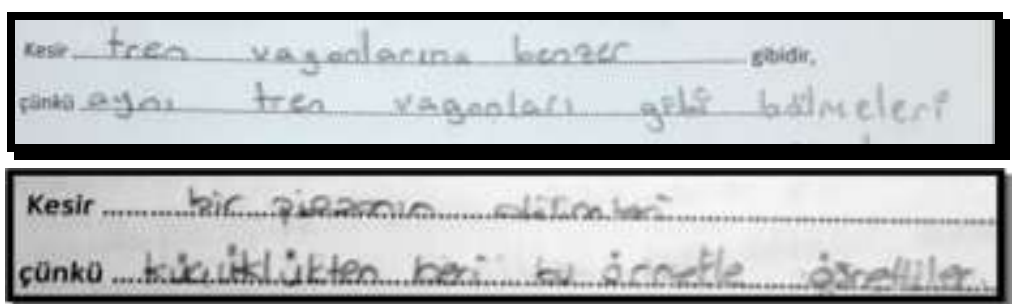

Şekil 1. "Somut bir nesne/Fiziksel olarak yapılan bir iş" Teması Altında Yer Alan Metaforlardan Örnekler

Araştırmaya katılan öğrenciler tarafından üretilen metaforların 80 (\%26.85)'i ikinci kategori olan "Soyut bir kavram" kategorisi altında yer almıştır. Bu metaforlar içinde en sık kullanılan metaforlar; "Hayat", "Matematik" ve "Geometrik şekiller" metaforlarıdır. Sınıf seviyesine göre bakıldığında ise, araştırmaya katılan beşinci sınıf öğrencilerinin ürettikleri metaforların sayısının (18 metafor-\%6.04), yedinci sınıf öğrencilerinin bu kategori altında yer alan metaforlarının (62 metafor-\%20.81) sayısına kıyasla oldukça az olduğu anlaşılmıştır. Bu durum, yine yedinci sınıf öğrencilerinin 12-13 yaş aralığında ve soyut işlemler dönemine geçmiş olan öğrenciler olmaları ile açıklanabilir. Aşağıda yer alan şekilde bu tema altında yer alan metaforlardan örneklere yer verilmiştir. 


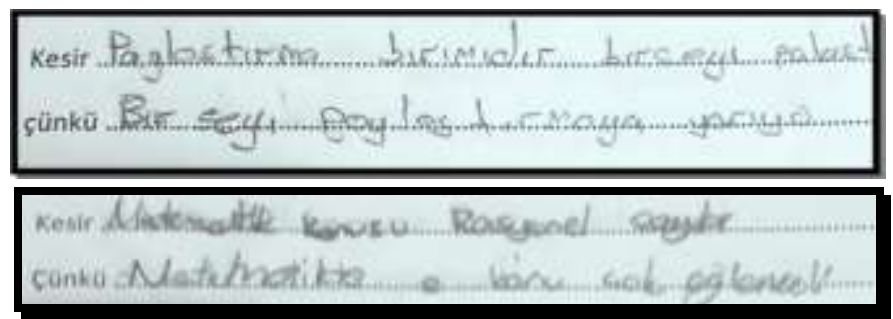

Şekil 2. "Soyut bir kavram" Teması Altındaki Metaforlardan Örnekler

Bu kapsamda, üçüncü tema olan "Kesir gösterimi ile ilişkili" teması için inceleme yapılmış ve öğrencilerin ürettiği metaforların 25 (\%8.39)'inin bu temada yer alan ve "Kesir" kavramına şekil yönünden yaklaşan öğrencilere ait metaforlar olduğu görülmüştür. Bu metaforlardan en sık kullanılanları "Tren”, "Kesen çizgi”, "İki odayı ayıran duvar", "Işın”, ve "Ayrı bölmeli eşyalar" isimli metaforlardır. Sınıf düzeylerinde yapılan incelemelerde, bu tema altında beşinci sınıf öğrencilerinin (20 metafor-\%6.71) yedinci sınıf öğrencilerine (5 metafor-\%1.68) kıyasla daha çok sayıda metafor ürettiği de görülmüştür. Bu gruptaki metaforların çoğunlukla beşinci sınıf öğrencileri tarafından üretilmiş olması, katılımcıların Piaget Bilişsel Gelişim Kuramı'na göre henüz göre somut işlemler döneminde olmalarına bağlanabilir. Somut işlemler döneminde, öğrenci var olan nesneleri gösteren sembollerle düşünürken, soyut işlemler dönemindeki birey mevcut olasılıklar üzerine düşünebilir (Cüceloğlu, 2000). Aşağıda yer alan şekilde de, bu tema altında yer alan metaforlardan örneklere yer verilmiştir.

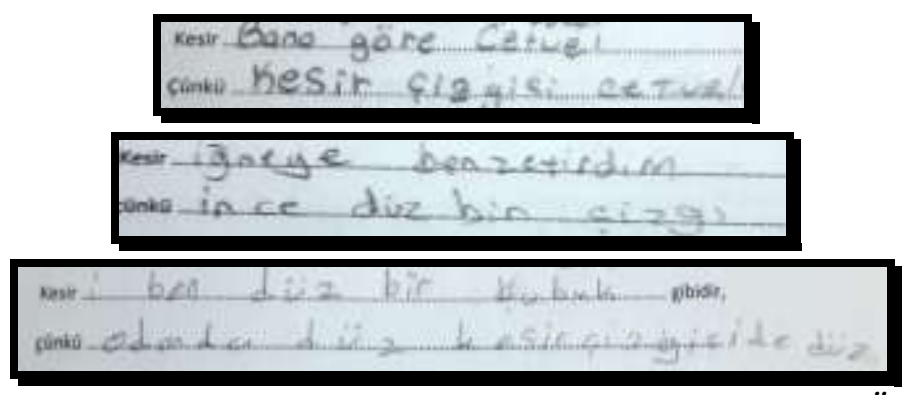

Şekil 3. "Kesir gösterimi ile ilişkili" Teması Altındaki Metaforlardan Örnekler

$\mathrm{Bu}$ araştırma kapsamında yapılan incelemelerde, araştırmaya katılan ortaokul beşinci ve yedinci sınıf öğrencilerinin ürettikleri metaforlardan 13 
(\%4.36)'ünün "Olumsuz algı" teması kapsamında yer alan öğrenci metaforları olduğu görülmüştür. Bu durum, araştırmaya katılan bazı öğrencilerin "Kesir" kavramı hakkında olumsuz algıları bulunduğuna işaret etmektedir. Bu metaforlardan en sık kullanılanları; "Kara delik", "Korku-dehşetkaranlık", "Bilgisayarın masaüstü ekranı", "Çaresi olmayan zehir”, “Güzellik" ve "Oyun" metaforlarıdır. Sınıf seviyesine göre bakıldığında ise, beşinci sınıf öğrencilerinin 3 (\%1.0) adet olumsuz metafor üretirken yedinci sınıf öğrencilerinin 10 (\%3.36) adet olumsuz metafor ürettiği görülmüştür. Üretilen metaforlar incelendiğinde, katılımcıların çoğunlukla kesir kavramının karmaşıklığına vurgu yapan, çözümü çok zor veya imkânsız olan sorunlar içeren metaforlar ürettikleri anlaşılmıştır. Aşağıda yer alan şekilde de, bu kategori altında yer alan metaforlardan örneklere yer verilmiştir.

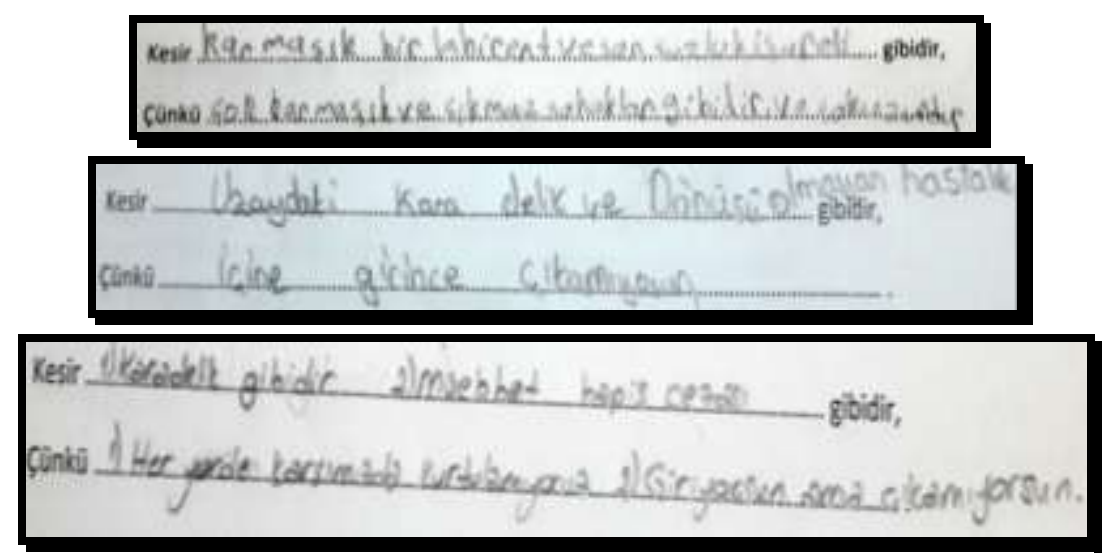

Şekil 4. "Olumsuz algı" Teması Altındaki Metaforlardan Örnekler

Araştırmaya katılan öğrencilerin ürettiği metaforların az bir kısmı (12 metafor-\%4.03) da beşinci tema olan "Benzetim" teması altında yer almıştır. Bu metaforlar; çoğunlukla kesir kelimesinin ismine ya da hecelerine benzetme, yabancı dillerdeki anlamına benzetme ve bir özel isime benzetme yoluyla üretilmiş olan metaforlardır. Sınıf seviyesine göre bakıld1ğında ise, araştırmaya katılan öğrencilerin ürettikleri metafor sayılarının birbirine eşit olduğu anlaşılmaktadır.

$\mathrm{Bu}$ araştırma kapsamında yapılan incelemelerde, araştırmaya katılan ortaokul öğrencilerinin geliştirdikleri metaforlardan 10 (\%3.35)'unun ise 
"Olumlu algı" teması kapsamında yer alan metaforlar olduğu görülmüştür. Bu durum, araştırmaya katılan çok az sayıda öğrencinin "Kesir" kavramı hakkında olumlu algıları bulunduğuna işaret etmektedir. Bu metaforlar; "Atom", "Arkadaşl1k", "Dünyanın en temel konusu", "Bölen", "Papatya", “Güzellik", “Oyun", “İnsan" ve "Menekşe" metaforlarıdır. Sınıf seviyesine göre bakıldığında ise, beşinci sınıf öğrencilerinin 3 (\%1.0) adet olumlu metafor üretirken yedinci sinıf öğrencilerinin 7 (\%2.35) adet olumlu metafor ürettikleri görülmüştür. Üretilen metaforlar incelendiğinde, olumlu metaforlar çoğunlukla eş parçaların birleşmesiyle ya da katılımcıların sevdikleri şeylere benzetilerek oluşturulduğu anlaşılmıştır. Aşağıda yer alan Şekil 5'te, bu kategori altında yer alan metaforlardan örneklere yer verilmiştir.

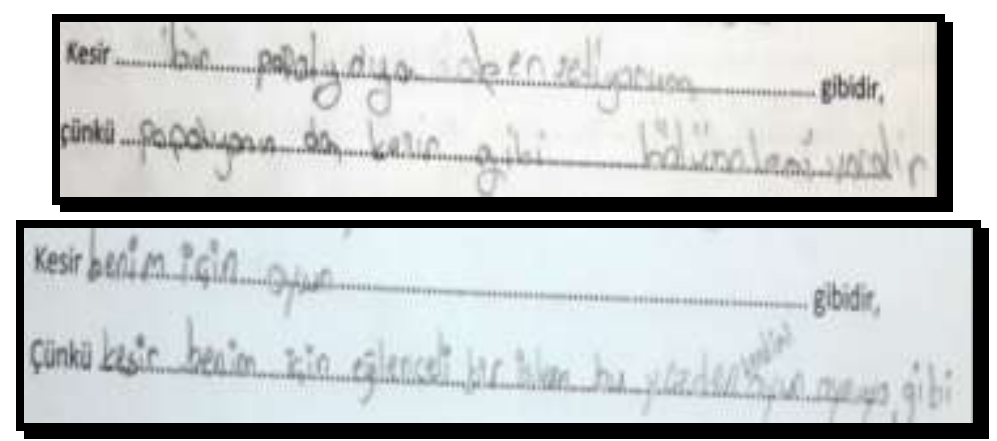

Şekil 5. "Olumlu algı" Kategorisi Altındaki Metaforlardan Örnekler

Olumlu algı metaforunda olduğu gibi, yedinci sınıf öğrencilerinin beşinci sınıf öğrencilerine kıyasla daha yüksek miktarda olumsuz metafor ürettikleri görülmüştür. Yedinci sınıf öğrencilerinin hem olumlu hem de olumsuz metafor üretme konusunda beşinci sinıf öğrencilerini geride b1rakmaları da, bu yedinci sınıf öğrencilerinin kesir kavramına ilişkin hislerini daha net bir biçimde açığa vurabildiklerine işaret edebilir.

\section{Tartışma ve Sonuç}

Bu çalışma kapsamında elde edilen araştırma bulguları, araştırmaya katılan beşinci ve yedinci sınıf öğrencilerinin "Kesir" kavramıla ilgili toplam 298 metafor ürettiklerini göstermiştir. Bu metaforlar arasında en çok üreti- 
len metaforlara bakıldığında, ortaokul öğrencilerinin çoğunlukla kesir kavramını eş parçalara bölünebilecek bir nesne ya da bir nesneyi eş parçalara ayırma işlemi olarak algıladıkları anlaşılmaktadır. Pesen (2007) tarafından üçüncü sınıf öğrencileri ile yapılan çalışmanın sonucunda kesirlere uygun model çizmede öğrencilerin önemli bir bölümünün bütünü eş parçalara ayırmada başarılı olamadıkları açıklanmıştır. Benzer şekilde, Önal ve Yorulmaz (2017) tarafından ilkokul dördüncü sınıf öğrencileri ile yapılan çalışmanın sonucunda da, sayı doğrusunda bütünü parçalara eş olarak ayırmama durumu olduğu ifade edilmiştir. Bu durum da, öğrencilerin kesri bir nesneyi eş parçalara ayırma işlemi olarak algılamakla birlikte kavramı öğrenmede başarılı olmadıklarına işaret edebilir. Bunun yanı sıra, beşinci sınıf öğrencileri de yedinci sınıf öğrencileri de ondalık kesre ilişkin bir metafor üretmezken, yalnızca bir tane yedinci sınıf öğrencisi rasyonel sayılarla kesir kavramını ilişkilendiren bir metafor üretmiştir. Bu durum da, öğrencilerin ondalık kesir kavramını kesir kavramının bir parçası olarak gördüklerini ve bunlar arasındaki ilişkiyi kavrayamadıklarını düşündürmektedir. Bunun nedenlerinden biri, öğrencilerin bir bölümünün a/b kesrini tek bir sayı olarak algılayamamaları şeklinde açıklanabilir. Ulaşılan bu sonuç, yine Pesen (2007) tarafından üçüncü sınıf öğrencilerinin kesirlerle ilgili ortak hatalarının incelendiği çalışmanın sonucunda ulaşılan bazı öğrencilerin kesrin sembolik gösterimini tek bir sayı olarak algılamada zorluk çektikleri sonucunu destekler niteliktedir.

$\mathrm{Bu}$ araştırma kapsamında, ortaokul öğrencileri en çok "Somut bir nesne/Fiziksel olarak yapılan bir iş" biçimindeki birinci tema altında somut metaforlar üretmişlerdir ki, bu durum kesir kavramının derslerde somutlaştırılarak işlenmesi ile ilişkili olabilir. Beşinci sınıf öğrencilerinin bu konudaki metaforlarının yedinci sınıflara kıyasla daha çok sayıda olması da, somut örnekler ve şekiller üzerinden uygulanan örneklere yer verilen "Kesir" kavramının ders programlarında ilk sinıftan itibaren yer alması ve soyut bilgiler içermekle birlikte ondalık ve yüzde çalışmalarını da kapsayan "Rasyonel sayılar/Rasyonel sayılarla işlemler" konularına da yedinci sınıftan itibaren yer verilmesi ile açıklanabilir. Beşinci sınıf öğrencilerinin somut kavramlar, yedinci sını öğrencilerinin de soyut kavramlara ilişkin daha çok sayıda metafor üretmeleri de, öğrencilerin içinde bulundukları bilişsel gelişim yaş grubu ile açıklanabilir. Ayrıca, bu kavram hakkında bazı öğrencilerin ürettikleri olumsuz metaforlar da, bu öğrencilerin kesir 
kavramını anlayamadıklarına işaret etmektedir. Ulaşılan bu sonuç da, Pesen (2007) tarafından yapılan çalışmanın sonucunda ulaşılan bulgular ile benzerlik göstermektedir.

$\mathrm{Bu}$ araştırmaya katılan öğrencilerin az bir bölümü de "Kesir" kavramının anlamından çok kesir kavramının gösterimine ilişkin, kesir kelimesini çağrıştıran kelimeler ve özel isimlerle metaforlar üretmişlerdir. Bu durum da, çoğunluğu beşinci sınıfta okumakta olan bu katılımcıların kesir kavramının anlamını ve kullanılma nedenini tam olarak kavrayamadıklarını düşündürmektedir. Bu nedenle, bu öğrencilerin kesir kavramının anlamından çok kesir kelimesine benzer kelimelerle ya da pay, kesir çizgisi ve paydanın oluşturduğu biçime benzeyen şekillerden metaforlar oluşturdukları söylenebilir. Ulaşılan bu sonuçlar da, yine Pesen (2007) tarafından yapılan çalışmanın bulgularını destekler niteliktedir.

Sonuç olarak, bu araştırma kapsamında ortaokul beşinci ve yedinci s1nıf öğrencileri tarafından kesir kavramına ilişkin soyuttan daha çok somut metaforlar ve olumlu düşüncelerden çok olumsuzluk içeren (karışık, çözülmesi zor ve sonu olmayan sorular yumağı şeklinde benzetmeler içeren) metaforlar üretilmiştir. Kesir kavramının öğretiminde çeşitli dijital ve somut materyaller içeren uygun öğretim teknikleri kullanılması, üretilen olumsuz metaforlara benzer öğrenci algılarının oluşumuna neden olan öğrenme ortamından uzak kalan öğrencilerin kesirle ilgili kavramları tam olarak anlayabilmesine ve dolayısıyla anlamlı öğrenmeyi gerçekleştirebilmesine katkı sağlayabilir. Bununla birlikte, "Kesir" kavramının etkili bir şekilde öğretimi birçok matematik konularının öğretiminde temel teşkil eden bir konu olması nedeniyle önemlidir. Bu nedenle, kesir kavramının ögretiminde verilecek örneklerden derste kullanılan yöntem ve tekniklere kadar tüm detayların dikkatle seçilmesi büyük önem arz etmektedir. Kesir kavramının öğretiminde, öğretmenlere rehber ve ilham kaynağı olabilecek ve sinıf ortamında verilen örneklerdeki detayların üzerinde durulduğu bir öğretimin planlanması faydalı olabilir. 


\title{
EXTENDED ABSTRACT
}

\section{Middle School Students' Metaphors about Fraction}

\author{
Hakan Ergöl - Dilek Sezgin Memnun \\ Ministry of National Education, Uludağ University
}

The numbers are based on the period before Christ into the lives of people. Built first and then the need for numbers, then the discovery of mathematics that emerged with a sense of curiosity and with the emergence of rational numbers in this process, mathematics numbers has been involved intensely in the history. The total number of people encounter in everyday life in solving situations that has led to the emergence of rational numbers is insufficient. In this context, the fraction has become increasingly a basic important concept that will be dealt with in this research, and calculations that are used in different field of expertise (Walle, Karp and Bay-Williams, 2013; Cited in Macit and Nacar, 2019).

The concept of fraction which exists in our daily lives and interdisciplinary studies is one of the concepts that students have difficulty in understanding and solving in mathematics teaching. After the recent changes in the mathematics program, teaching this concept through concrete materials and familiar objects that they know in their lives has gain importance. Because, teaching of the concept of fraction is given from the first grade of primary school in these program changes. Following these changes and innovations, there is a need to re-examine the ways which students perceive the concept of fraction in the context of mathematics teaching. Therefore, it was examined the perspectives of the fifth and seventh grade students on the concept of fraction and the perception ways of the fraction concept of the fifth and seventh grade students; and in this context it is aimed to reveal the metaphors of the concept of fraction of middle school students who participated in the research. In addition, the analysis of the differences between the metaphors produced by the fifth and seventh grade students were also indicated in this research. With this aim, the answers were sought for the following research questions: 
1. What were the metaphors which the middle school students have in relation to the concept of fraction?

2. Under which conceptual themes could the metaphors which the middle school students had in relation to the concept of fraction be gathered in terms of common characteristics?

3. Were there any different themes for fifth and seventh grade students seperated from each other?

A total of 298 fifth and seventh grade students, who were studying at a middle school in Istanbul during the 2017-2018 second semester, including 152 fifth grade and 146 seventh grade students attended in this study. These students were asked to answer the phrase of "fraction is like.....because....." to understood their mental images. Students were given sheets and wanted to write their thoughts by one image.

The data of the research was analyzed through descriptive analysis method. The descriptive analysis is a type of qualitative data analysis that contains the interpretation and summarized according to predetermined themes obtained with various data collection techniques. The main aim of this type of analysis is to interpret of the findings which have been achieved is summarized and presented in a format for the reader (Yıldırım and Şimşek, 2005). Descriptive analysis consists of four steps. These are; to create a framework for descriptive analysis, thematic data analysis according to the framework, description of findings, and interpretation of the findings (Altunışık, Coşkun, Yıldırım and Bayraktaroğlu, 2010). Within the scope of this research, first research problem was established the framework for data analysis at the most general level in the first stage in the process of developing a framework for descriptive analysis. According to the thematic framework to the data processing stage, for the first research problem data was classified and presented in six different theme as a tangible object/physically work, an abstract concept, simulation, negative perception, positive perception and related with fraction notation according to the specified frame. In the identification and interpretation of the findings phase, the data obtained was read and edited according to the identified themes. Then, the edited data in the tables and figures are presented and the results achieved through these themes have been interpreted. Finally, the research findings were supported with direct quotations where necessary. The fifth and seventh grades' words and explanations were analyzed using the Microsoft Excel program. 
Through this study, it was observed that the students who participated in the research mostly consisted of "cake / pizza", "knife / scissors", "shredding whole" and "life" metaphors. Nevertheless, it was understood that seventh grade students explained the concept of fraction by using more abstract metaphors than fifth grade students. Also, when the metaphors produced by some of the students were examined, it was understood that these students could not fully understand the meaning and the purpose of the concept of fraction.

\section{Kaynakça / References}

Altunışık, R.,Çoşkun, R., Yıldırım, E., ve Bayraktaroğlu, S. (2010). Sosyal bilimlerde araştırma yöntemleri (6.Baskı). Sakarya: Sakarya Kitabevi.

Baykul, Y. (1999). Illköğretimde matematiköğretimi-1.ve 5. sinıflar. Ankara: Anı.

Birgin, O. ve Gürbüz, R. (2009). İlköğretim II. kademe öğrencilerinin rasyonel sayılar konusundaki işlemsel ve kavramsal bilgi düzeylerinin incelenmesi. Uludă̆ Üniversitesi Ĕ̆itim Fakültesi Dergisi, XXII(2), 529-550.

Büyüköztürk Ş., Kılıç-Çakmak, E., Akgün, Ö.E., Karadeniz Ş., ve Demirel, F. (2012). Bilimsel araştırma yöntemleri (11.Baskı). Ankara: Pegem.

Charalambous C.Y. ve Pantazi, D.P. (2005). Revisiting a theoretical model on fractions: Implications for teaching and research. In Chick, H.L. ve Vincent, J.L. (Eds.), Proceedings of the 29th Conference of the International Group for the Psychology of Mathematics Education (Vol 2, p. 233- 240).

Cropley, A. (2002). Qualitive research methods: An introduction for students of psychology and education. University of Latvia: Zinatne.

Cüceloğlu, D. (2000). İnsan insana. İstanbul: Remzi Kitabevi.

Doğan, M. ve Yeniterzi, B. (2011). İlköğretim 7. sınıf öğrencilerinin rasyonel sayılar konusundaki hazır bulunuşlukları. Selçuk Üniversitesi Ahmet Keleşoğlu Eğitim Fakültesi Dergisi, 31, 217-237.

Haser, Ç. ve Ubuz, B. (2002). Kesirlerde kavramsal ve işlemsel performans. Ĕ̆gtim ve Bilim, 27(126), 53-61.

Lamon, S.J. (2007). Rational numbers and proportional reasoning: Toward a theoretical framework for research. Second Handbook of Research on Mathematics Teaching and Learning, 1, 629-667.

Macit, E. ve Nacar, S. (2019). İlköğretim matematik öğretmenliği öğrencilerinin rasyonel sayı ve kesir kavram imajları. İnönü Üniversitesi Eğitim Bilimleri Enstitüsü Dergisi, 6(11), 50-62. 
Millî Eğitim Bakanlığı (2018). Matematik dersi öğretim programı (İlkokul ve Ortaokul 1, 2, 3, 4, 5, 6, 7. ve 8. sinıflar). Ankara: Milli Eğitim Basımevi.

Orhun, N. (2007). Kesir işlemlerinde formal aritmetik ve görselleştirme arasındaki bilişsel boşluk. Inönü Üniversitesi Eğitim Fakültesi Dergisi, 8(14), 99-111.

Önal, H. ve Yorulmaz, A. (2017). İlkokul dördüncü sınıf öğrencilerinin kesirler konusunda yaptıkları hatalar. Eğitim ve Toplum Araştırmaları Dergisi, $4(1), 98-113$.

Pesen, C. (2007). Öğrencilerin kesirlerle ilgili kavram yanılgıları. Eğitim ve Bilim, 32(143), 79-88.

Senemoğlu, N. (2009). Gelişim, öğrenme ve öğretim kuramdan uygulamaya. Ankara: Pegem.

Soylu, Y. ve Soylu, C. (2005). İlköğretim beşinci sınıf öğrencilerinin kesirler konusundaki öğrenme güçlükleri: Kesirlerde sıralama, toplama, çıkarma, çarpma ve kesirlerle ilgili problemler. Erzincan Eğitim Fakültesi Dergisi, 7(2), 101-117.

Şiap, İ. ve Duru, A. (2004). Kesirlerde geometriksel modelleri kullanabilme becerisi. Gazi Üniversitesi Kastamonu Ĕ̆itim Dergisi, 12(1), 89-96.

Türk Dil Kurumu (2019). Türk Dil Kurumu sözlüğ̈̈. 12.06.2019 tarihinde sozluk.gov.tr adresinden edinilmiştir.

Yazgan, Y. (2007). 10-11 yas grubundaki öğrencilerin kesirleri kavramalar üzerine deneysel bir çalısma. Yayımlanmamış Doktora Tezi, Uludağ Üniversitesi Sosyal Bilimler Enstitüsü, Bursa.

Yıldırım, A. ve Şimşek, H. (2005). Sosyal bilimlerde nitel araştırma yöntemleri (Beşinci basım). Ankara: Seçkin Yayıncılık.

Yılmaz, Z. ve Yenilmez, K. (2009). İlköğretim 7. ve 8. sınıf öğrencilerinin ondalık sayılar konusundaki kavram yanılgıları:Uşak ili örneği. Afyon Kocatepe Üniversitesi Fen Bilimleri Dergisi. 8(1), 269-29.

\section{Kaynakça Bilgisi / Citation Information}

Ergöl, H. ve Sezgin Memnun, D. (2020). Ortaokul öğrencilerinin kesir kavramına ilişkin ürettikleri metaforlar. OPUS-Uluslararası Toplum Araştırmaları Dergisi, 15(23), 1920-1939. DOI: 10.26466/opus.639306 